\title{
Heat Shock Protein 90 Alpha Genes Are Up-regulated by Acute Exercise
}

\author{
Ehiaghe Friday Alfred 1, 2, 3, 4, *, Digban Kester², Ehiaghe Imuetiyan Joy ${ }^{3}$ \\ ${ }^{1}$ Department of Hematology and Immunohematology, College of Health Sciences, Igbinedion University, Okada, Nigeria \\ ${ }^{2}$ Department of Medical Laboratory Science, College of Health Sciences, Igbinedion University, Okada, Nigeria \\ ${ }^{3}$ Lahor Research and Medical Centre, Benin City, Nigeria \\ ${ }^{4}$ Department of Medical Laboratory Science, Nnamdi Azikiwe University, Awka, Nigeria
}

Email address:

fredleo2547@yahoo.com (E. F. Alfred)

${ }^{*}$ Corresponding author

\section{To cite this article:}

Ehiaghe Friday Alfred, Digban Kester, Ehiaghe Imuetiyan Joy. Heat Shock Protein 90 Alpha Genes Are Up-regulated by Acute Exercise. Advances in Biochemistry. Vol. 5, No. 4, 2017, pp. 57-60. doi: 10.11648/j.ab.20170504.11

Received: March 22, 2017; Accepted: April 15, 2017; Published: July 5, 2017

\begin{abstract}
This study was designed to further determine the expression pattern and role of heat shock protein 90 alpha genes in pre and post acute exercise amongst young male undergraduates in Nnewi, Nigeria. Twenty five (25) healthy young male undergraduate students with an average age of $24.3 \pm 3$ years and body mass index of $22.7 \pm 1.8\left(\mathrm{Kg} / \mathrm{m}^{2}\right)$ participated fully in the study. The subjects took part in an endurance race using the Bruce treadmill protocol for sub-maximal exercise for a maximum of 21 minutes. Blood samples were collected from the participants before commencement of the study, at 1 hour, 4 hours and 24 hours post exercise. Heat shock protein 90 alpha genes expression patterns were detected using reverse transcriptase polymerase chain reaction method. The expression pattern of heat shock protein 90 alpha genes was up-regulated at 1 hours post exercise and sustained till 24 hours post exercise at 200bp in all the exercised subjects when compared with the pre-exercise stage. Post exercise stress activates the release of heat shock protein 90 alpha genes which are needed to restore cellular homeostasis.
\end{abstract}

Keywords: Acute Exercise, Heat Shock Protein 90 Alpha, Stress, Up-regulation

\section{Introduction}

1. Physical exercise is important for maintaining physical fitness and can contribute positively to maintaining a healthy weight, muscle strength, promoting physiological well-being and strengthening the immune system [1-3]. Physiological stress represents a wide range of physical responses that occur as a direct effect of a stressor causing an upset in the homeostasis of the body [4].The synthesis of heat shock protein in cells is induced by various environmental factors, pathological conditions, and physiological stresses [5]. Post exercise stress has been reported to cause up-regulation of several genes in the human body which are needed to maintain cellular homeostasis [6-9].

The specific function of heat shock protein 90 genes has not yet fully been comprehended in sport medicine. It has been postulated that the expression of heat shock proteins convey a response initiated to maintain cellular homeostasis after exposure to stress [10]. This study was designed to further determine the expression pattern and role of heat shock protein 90 alpha genes in pre and post acute exercise amongst young male undergraduates in Nnewi, Nigeria. Gaining an understanding of the pattern of expression of heat shock proteins will aid exercise physiologist in ascertaining how exercise may provide protection to cells and tissues either for health and occupational reasons. This will add to the existing level of information on exercise which is beneficial.

\section{Materials and Methods}

\subsection{Subjects}

The study was carried out in the Faculty of Health Science 
and Technology, Nnamdi Azikiwe University, Nnewi Campus. Twenty five (25) healthy young male undergraduate students with an average age of $24.3 \pm 3$ years and body mass index of $22.7 \pm 1.8\left(\mathrm{Kg} / \mathrm{m}^{2}\right)$ participated fully in the study. Patient consent was obtained from the subjects.

\subsection{Inclusion Criteria}

This study was delimited to apparently healthy young male undergraduate students of the Faculty of Health Sciences, Nnamdi Azikiwe University, Nnewi Campus within 18 and 35 years of age who are willing to participate in the study.

\subsection{Exclusion Criteria}

Young male with an underlying history of illness e.g. Hypertension, irregular heart rate, glucose utilization disorders, asthmatics, sickle cell anemia and other forms of anemia were excluded.

\subsection{Research Design}

The research design was an interrupted time series design.

\subsection{Study Design}

The subjects were encouraged to eat balance diet two hours prior to the endurance race and avoid any strenuous activity during the course of the research. Upon arrival at the venue of the research, their height $(\mathrm{H})$ and weight $(\mathrm{W})$ was measured and recorded and they were allowed to rest for at least ten minutes. The subjects were stressed to exhaustion using the Bruce treadmill protocol for sub maximal exercise. The exercise-induced stress protocol started at $2.7 \mathrm{~km} / \mathrm{hr}$ and a $10 \%$ grade and increased by $2 \%$ every 3 minutes in a steplike manner to a final stage at $9.6 \mathrm{~km} / \mathrm{hr}$ with a $22 \%$ grade as described by Vanessa and Elizabeth [11].

The target heart rate on the treadmill was $60-80$ percent of the heart rate maximal reserve (HRR).The difference between maximal heart rate (MHR) and resting heart rate (RHR).

The HRR was calculated using the formula:

$$
H R R=M H R-R H R \text {. }
$$

MHR=220-Age in years.

As described by Ehiaghe et al. [12]. The subjects continued this for twenty one minutes or stopped when they are tired. Fourteen out of twenty five subjects were exhausted before the twenty-one minutes.Blood sample was collected at four different time points: before, one hour, four hours and twenty four hours post exercise stages.However, this study design was not able to control the effects of heat gain during exercise.

\subsection{Collection of Blood Samples}

Six milliliters of venous blood sample were collected from the medial cubital vein using vacutainer and needle from each of the subjects shared equally into ethylene diamine tetra acetic acid containers and RNAgard vacutainer for total lymphocyte RNA isolation.

\subsection{Polymerase Chain Reaction Methods}

\subsubsection{Total RNA Extraction Using the ZYMO Research Whole-Blood RNA MiniPrep}

Total RNA was extracted using the ZR Whole -Blood RNA MiniPrep with catalog number R1020 and R1021 by Zymo Research Corporation according to manufacturer's specification at the Lahor Research Laboratory and Medical centre, 121 Old Benin- Agbor Road, Benin City, Edo State, Nigeria. $70 \mu \mathrm{l}$ of the Total RNA extracted was transferred into an RNA stable tube supplied by Biomatrica with catalog number 93221-001 for storage of Total RNA at room temperature after proper drying.

\subsubsection{One Taq One-Step Reverse Transcriptase Polymerase Chain Reaction}

The extracted Total RNA was retro-transcribed and amplified using One Taq One Step RT-PCR kit with catalog number NEB E5315S by NEW ENGLAND BioLabs incorporation according to the manufacturer's specification. Heat shock protein $90 \alpha$ forward and reverse primers (ACCCAGACCCAAGACCAACCG;ATTTGAAATGAGCT CTCTCAG) were used to target the extracted template using Peltier thermal cycler polymerase chain reaction machine at the Lahor Research Laboratory and Medical Centre, 121, Old Benin-Agbor Road, Benin City, Edo state, Nigeria. The system components were thawed and mixed by inverting ten times. The PCR was performed in a $50 \mu$ l reaction mixture containing $25 \mu \mathrm{l}$ One Taq one-step reaction master mix $(2 \mathrm{x})$, $2 \mu l$ One Taq one- step enzyme mix $(2 x), 2 \mu l$ of each genespecific forward primer $(10 \mu \mathrm{M}), 2 \mu \mathrm{l}$ of each gene-specific reverse primer $(10 \mu \mathrm{M}), 9 \mu \mathrm{l}$ of nuclease-free water and $10 \mu \mathrm{l}$ of the RNA template(s) was added last. The PCR condition was programmed as follows: Reverse transcription at $48^{\circ} \mathrm{C}$ for 30 minutes, initial denaturation at $94^{\circ} \mathrm{C}$ for 1 minute, denaturation at $94^{\circ} \mathrm{C}$ for 15 seconds, annealing at $53^{\circ} \mathrm{C}$ for 30 seconds, extension at $68^{\circ} \mathrm{C}$ for 1 minute, Go to the denaturation step for 39 cycles, final extension at $68^{\circ} \mathrm{C}$ for 5 minutes and final holding at $4^{\circ} \mathrm{C}$. Five micro liters of the amplified PCR products were analyzed on $1 \%$ agarose gel containing ethidium bromide in $1 \mathrm{X}$ Tris EDTA buffer. Electrophoresis was performed at $90 \mathrm{~V}$ for 30 minutes with the EDVOTEK tetra source electrophoresis machine, Bethesda, USA. The targeted genes were visualized by Wealtec Dolphin-Doc UV transilluminator and photographed. Molecular weights were calculated using molecular weight standard of the marker. The graphical analysis was done on a bar chart.

\subsection{Statistical Analysis}

Gene expression results were analyzed with Pearson ChiSquare test using SPSS version 20.0 statistical program. P values $<0.05$ were considered significant. 


\subsection{Ethics}

Ethical approval were obtained from the Ethics Committee of the Faculty of Health Science and Technology, Nnamdi Azikiwe University, Nnewi Campus and Lahor Research Laboratory and Medical centre in Benin City, Edo State, Nigeria with reference number LRL/ 005/014.

\section{Results}

The study revealed that heat shock protein 90 alpha genes was up-regulated at 1 hours post exercise and sustained till 24 hours post exercise at $250 \mathrm{bp}$ in the twenty-five exercised subjects when compared with the pre-exercise stage (Figure 1 and Figure 2) respectively.

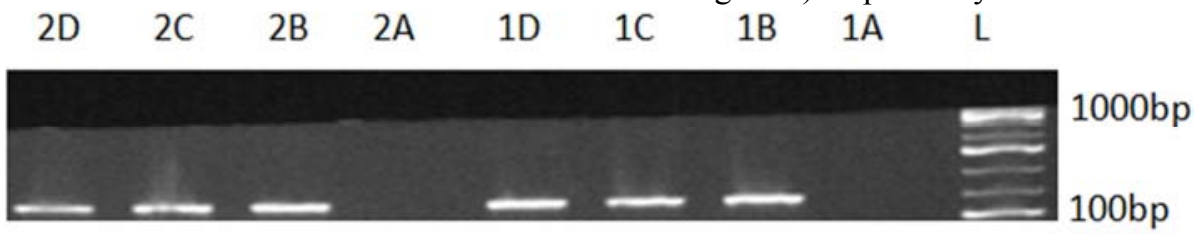

Figure 1. Reverse transcriptase PCR results for heat shock protein alpha genes analyzed on a $1.0 \%$ agarose gel electrophoresis stained with ethidium bromide. $L$ is a 100bp DNA ladder (molecular marker) extending from 100bp to 1000bp. Lanes $1 B, 1 C, 1 D, 2 B, 2 C$ and $2 D$ are positive bands for the expressed heat shock protein alpha genes at 200bp from the exercised subjects. Lanes $1 \mathrm{~A}$ and 2 Aare negative bands from the pre stage of the exercise.

Keys:

$\mathrm{A}=$ pre-exercise

$\mathrm{B}=1$-hour post exercise

$\mathrm{C}=4$-hours post exercise

$\mathrm{D}=24$-hours post exercise

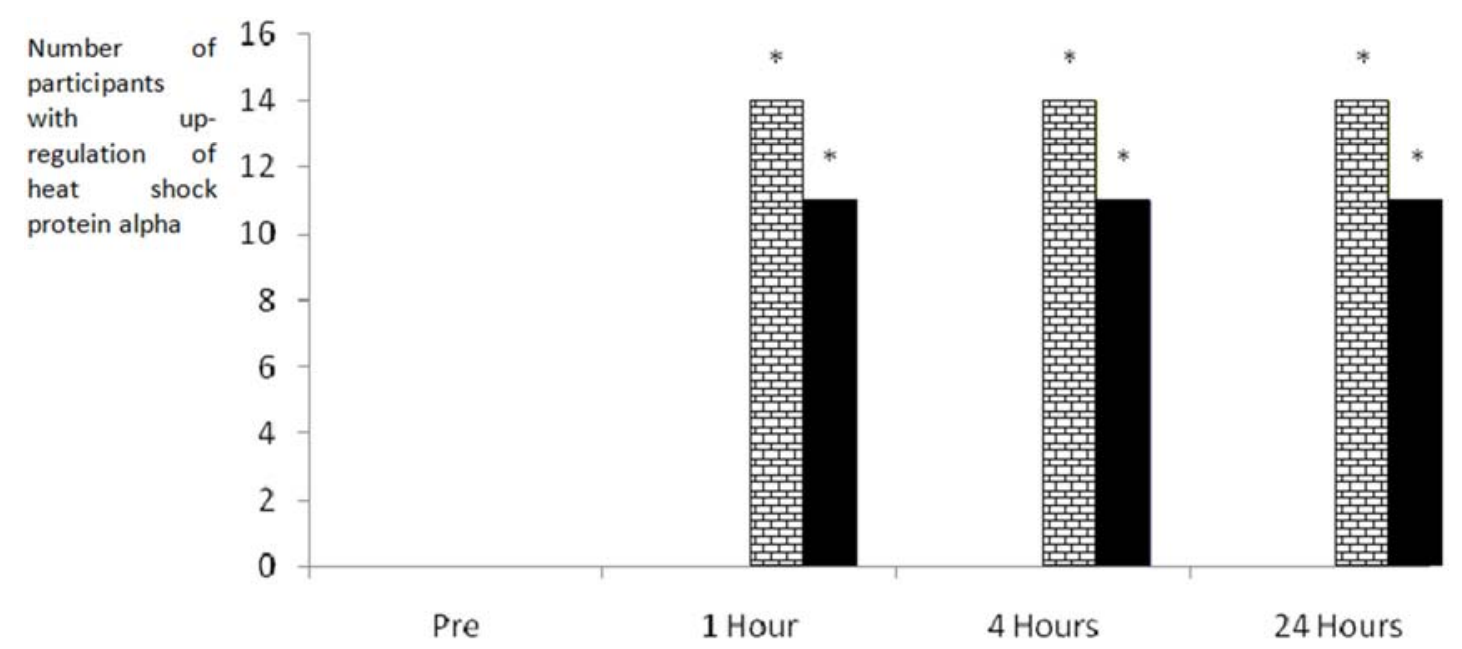

Figure 2. An overall multiple bar chart representation of the up-regulation of heat shock protein alpha gene detected in exercised subjects at different time intervals. The expression patterns were up-regulated at 1 hour post exercise and sustained till 24 hours post exercise $\left(\chi^{2}=50, P=0.000\right)$ respectively.

Keys:

Pre $=$ Gene not expressed in exercised participants

Bricks $=$ Gene expression in subjects who were exhausted before 21 minutes at different time intervals

Black $=$ Gene expression in subjects who were exhausted at 21 minutes at different time intervals

$*=$ Significant $\mathrm{P}<0.05$

\section{Discussion}

The expression pattern of heat shock protein 90 alpha genes was up-regulated at 1 hour post exercise and sustained till 24 hours post exercise at 200bpin the exercised subjects when compared with the pre-exercise stage (Plate 1) and Fig. 1. The possible mechanism of the up-regulation of the heat shock protein 90 alpha gene expression patterns observed in this study could be linked to adenosine triphosphate depletion, accumulation of adenosine diphosphate, and adenosine monophosphate due to consumption of adenosine triphosphate (ATP) by the exercising muscles [13]. An upregulation of heat shock proteins during or post-exerciseis indicative of an enhanced heat shock proteins (HSP) transcription rate which is needed to maintain cellular homeostasis $[14,15]$.Post exercise stress has been reported to cause up-regulation of several genes in the human body including heat shock protein genes [6-8]. Post exercise immune responses to stress are induced by local accumulation of energy regulatory molecules such as adenosine monophosphate (AMP), adenosine diphosphate (ADP), calcium ions and free radicals in the contracting muscle cells [16].

The expressions of heat shock proteins during or postexercise may convey a response initiated to maintain cellular homeostasis [10]. It is possible that the increased ATP 
utilization during and post acute exercise enhances the expression of heat shock protein alpha genes which are needed to restore homeostasis as the subjects feel relieved of the stress induced by the exhaustive exercise bout. Although a number of afferent stimuli such as hyperthermia, ATP depletion, hypoxia, exercise, and reactive oxygen species generation have been proposed for the up-regulation of heat shock proteins synthesis which are needed to maintain homeostasis during stress response [10, 17-19]. Some group of lymphocyte genes such as succinate dehydrogenase genes, hypoxanthine-guanine phosphoribosyl transferase genes, tumor necrosis factor alpha genes, interferon gamma genes and interleukin-10 geneshad been shown to be up-regulated in acute exercise in our previous studies [12, 20-21]. The duration of expression of such genes may be an indication of possible role in mediating response to stress.

\section{Conclusion}

Post exercise stress activates the release of heat shock protein 90 alpha genes which are needed to restore cellular homeostasis during stressful events. The findings further demonstrated that heat shock protein $90 \alpha$ genes had early and stable gene expression patterns that lasted for 24-hours suggesting that these genes can be used as reference gene to confirm evidence of stress.

\section{References}

[1] Stampfer, MJ., Hu, FB., Manson, JE., Rimm, EB., Willet, WC. Primary prevention of Coronary Heart Disease in Women through Diet and Lifestyle. New England Journal of Medicine.2000.343(1): 16-22.

[2] Hu, FB., Manson, J., Stampfer, M., Graham, C.Diet, Lifestyle and risk of type 2 diabetes mellitus in women. The New England journal of Medicine.2001.345 (11): 790 - 797.

[3] Gosker, HR., Scholes, AM. Fatigued muscles in COPD but no finishing line in sight. European Respiratory Journal. 2008.31:693-694.

[4] Koolhaas, J. Stress revisited: A critical evaluation of the stress concept. Neuroscience andBehavioralReviews. 2011.35:12911301.

[5] Linquist, S. The heat-shock response. Annual Review of Biochemistry. 1986.55: 1151-1191.

[6] Abdalla, A O., Kiaii, S., Hansson, L., Rossmann, E.D., JeddiTehrani, M., Shokri, F., Osterborg, A., Mellstedt, H., Rabbani, $\mathrm{H}$. Kinetics of cytokine gene expression in human CD4 + and CD8+ lymphocyte subsets using quantitative real-time PCR. Scandinavian Journal of Immunology. 2003.58: 601- 606.

[7] Katia, C., Michela, F., Stefano, C., Giacomo, S., Maurizio, S.A.V. Exercise induced stress in horses: Selection of the most stable reference genes for quantitative RT-PCR normalization.BMC Molecular Biology. 2008.9: 49-51.
[8] Bermudez, DM., Canning, DA., Liechty, KN. Age and proinflammatory cytokine production: Wound-healing implications for scar-formation and the timing of genital surgery in boys. Journal of Pediatric Urology. 2011.7: 324331.

[9] Josef, F. Biomarkers of peripheral muscle fatigue during exercise. Musculoskeletal Disorders. 2012.13: 213- 218.

[10] Lars, MN, Ric, L, Leigh, M. Heat shock proteins in exercise: A review. Journal of Exercise Science and Physiotherapy. 2006.2: 13-26.

[11] Vanessa, N. and Elizabeth, D. Submaximal exercise testing: Clinical application and interpretation. Journal of the American Physical Therapy Association.2000.80: 782- 807.

[12] Ehiaghe F A, Onyenekwe C C, Akosile C O, Ehiaghe IJ, Oyeyemi A W, Ifeanyichukwu M O. Some lymphocytic gene expression patterns associated with acute exercise in young male undergraduates. American Journal of Biotechnology and Molecular Science. 2016, 5: 8-22.

[13] De-Quevain, DJ., Roozendaal, B., Nitsch, RM., McGaugh, JL., Hock, C. Acute cortisone administration impairs retrival of long-term declaration memory in humans. Nature Neuroscience. 2005.4: 313- 314.

[14] Febbrio, MA, Koukoulas, I. HSP72 gene expression progressively increases in human skeletal muscles during prolonged exhaustive exercise. Journal of Applied Physiology. 2000. 89: 1055-1060.

[15] Fehrenbach, E., Passek, F., Niess, AM., Pohla, H., Weinstock, C., Dickhuth, H., Northoff, H. HSP expression in human leukocytes is modulated by endurance exercise. Medical Science. Sports and Exercise. 2000.32: 592-600.

[16] Vamshi, KRG. Biological scavengers of free radicalantioxidant: International Journal of Pharmaceutical Biology and Chemical Science.2012.1: 13-19.

[17] Giaccia, AJ., Auger, EA, Koong, A., Terris, DJ, Minchinton, AI, Hahn, GM, Brown, JM. Activation of heat shock transcription factors by hypoxia in normal and tumor cell lines in vivo and I vitro. International Journal of Radiation Oncology. Biol. Phys.1992. 23: 891-897.

[18] Locke, M., Noble, EG. Stress proteins: The exercise response. Canadian Journal Applied Physiology. 1995.20: 155-167.

[19] Kim, D., Ouyany, H., Li, GC. Heat shock protein HSP70 accelerates the recovery of heat shocked mammalian cells through its modulation of heat shock transcription factor HSFI Proceedings of the National Academy Sciences.1995. 92: 2126-2130.

[20] Ehiaghe FA, Onyenekwe CC, Akosile CO, Okoye C, Maruf FA, Agbonlahor DE, Uwabor CI, Ehiaghe IJ, Ogbu EC. The expression pattern and role of interferon gamma genes in exhaustive exercise. Journal of Advance in Biology. 2016. 9: 1903-1910.

[21] Ehiaghe FA, Onyenekwe CC, Ehiaghe IJ, Akosile CO, Agbonlahor DE. The role of cortisol and interleukin-10 gene expression patterns in exhaustive exercise. International Journal of Biological and Chemical Sciences. Accepted. 